\title{
Identifying food marketing to teenagers: a scoping review
}

\author{
Emily Truman * (D) and Charlene Elliott
}

\begin{abstract}
Background: Teenagers are aggressively targeted by food marketing messages (primarily for unhealthy foods) and susceptible to this messaging due to developmental vulnerabilities and peer-group influence. Yet limited research exists on the exposure and power of food marketing specifically to teenage populations. Research studies often collapse "teenagers" under the umbrella of children or do not recognize the uniqueness of teen-targeted appeals. Child- and teen-targeted marketing strategies are not the same, and this study aims to advance understanding of teen-targeted food marketing by identifying the teen-specific promotion platforms, techniques and indicators detailed in existing literature.
\end{abstract}

Methods: A systematic scoping review collected all available literature on food marketing/advertising with the term "teenager" or "adolescent" from nine databases, as well as Google Scholar for grey literature, and a hand search of relevant institutional websites. Included were all peer-reviewed journal articles, book chapters, and grey literature in which food marketing to youth was the central topic of the article, of any study type (i.e., original research, reviews, commentaries and reports), and including any part of the 12-17 age range.

Results: The 122 articles reviewed define the scope of existing literature on food marketing to young people age 17 and under, identifying leading trends in countries studied (United States, 52\%), populations identified (children and teens studied concurrently, 36\%), outcomes measured (advertising exposure, 54\%), study type (cross-sectional, 58\%) and methods used (content analysis, 46\%). The promotion platforms and techniques used by food marketers to appeal to young people (as reported in the literature) are also identified and classified. Few studies (7\%) use indicators to identify teen-targeted food marketing.

Conclusions: Unique treatments of teen populations are limited in food marketing literature, as is the application of clear indicators to identify and differentiate teen-targeted food marketing from child- or adult-targeted content. Given the need to better measure the presence and power of teen food marketing, this is a significant oversight in existing literature. The indicators identified will help researchers to develop more accurate strategies for researching and monitoring teen-targeted food promotion.

Keywords: Food marketing, Teenager, Adolescent, Scoping review, Food advertising, Exposure, Power, Monitor, Policy, Indicator

\section{Background}

Regulations limiting food marketing often focus on children under age 13, despite the fact that teenagers are also susceptible to food marketing appeals [1]. Teenage vulnerability to food marketing, and especially digital promotions, stem from unique developmental factors (i.e. cognitive and emotional) [2, 3],

\footnotetext{
* Correspondence: emily.truman@ucalgary.ca

Department of Communication, Media and Film, University of Calgary, 2500 University Drive NW, Calgary, Alberta T2N 1N4, Canada
}

peer-group influence $[4,5]$, and high levels of exposure to advertising messages [1,6-10]. Yet research on the impact of food marketing to teenagers is limited $[7,10-12]$. Teenagers, moreover, are often assessed as part of the broader category of children instead of as a unique population [11]. In fact, very few studies define or provide criteria to identify teen targeted food marketing. This scoping review examines existing studies on food marketing/advertising involving teenage populations (ages 12-17) in order to identify the

(c) The Author(s). 2019 Open Access This article is distributed under the terms of the Creative Commons Attribution 4.0 International License (http://creativecommons.org/licenses/by/4.0/), which permits unrestricted use, distribution, and 
scope of current research, including age ranges, outcomes, promotion platforms, techniques, and indicators. Specifically, the identification of indicators will provide a firm set of criteria for measuring the presence and power of teen-targeted food marketing.

Determining how to better identify teen-specific marketing appeals will allow for the monitoring of exposure and message content in order to inform regulatory policies on food marketing to teenagers. While many studies examine child-specific food marketing content (for example, the use of cartoon characters and 'fun' appeals [13-24]), little research isolates and identifies teen appeals. This is significant for teenage health since teenagers may be targeted more heavily by food marketers who are prohibited from appealing to children; it is also relevant to children, who may be attracted to teen-targeted content (WHO, 2018). Globally many countries recognize the deleterious effects of food promotion on children's health, and have restricted or prohibited the marketing of unhealthy foods [7, 25]. Canada is also aiming to restrict food marketing to children under Bill S-228, the Child Health Protection Act, which is currently awaiting approval by the Senate [26]. However, such restrictions do not apply to teenagers, even though teenagers are influenced by marketing appeals. Indeed, teenagers' awareness of, or cynicism towards, advertising messages does not necessarily make them more critical consumers or less persuaded by advertising [7, 11]. In light of the need for expanded knowledge around teen food marketing, this review is guided by the following research questions: 1) how do existing studies identify teenage populations (i.e., age range, collapsed into child populations, etc.)?; 2) how is teen-targeted food marketing identified and measured?; 3) what promotional platforms and techniques are examined?; and 4) what criteria or 'indicators' are used to isolate teen-specific appeals?

\section{Methods}

\section{Literature search}

A systematic search of all available English language literature (all dates up to July 2018) was conducted using the following search terms: (teenager OR adolescent) AND "food marketing"; (teenager OR adolescent) AND "food advertising". Databases used included Scopus, Web of Science, Embase, Medline, JSTOR, CAB Abstracts, CINHAL, and PubMed. Google Scholar was used to locate grey literature: the first 800 entries in the search return list were scanned, as per the recommended protocol for topic searches, which identifies saturation at page 80 [27]. A hand search was also conducted of the websites for the World Health Organization (WHO), the Federal Trade Commission
(FTC), and the Institute of Medicine (IOM). Figure 1 outlines the search strategy.

\section{Inclusion criteria}

All peer-reviewed journal articles, book chapters, and grey literature examining food marketing to youth as the central topic were included, along with any study in which any individual in the age 12-17 range appeared (whether labelled as 'teenager' or overlapping with/collapsed into 'child' or 'adult' categories). Included were all study types (including original research, reviews, commentaries and reports) and all food promotion platforms and techniques. Excluded were studies that examined whole foods (as opposed to packaged/processed food), alcohol advertising, parental opinions about food marketing to teenagers, and general screen time exposure (compared to screen time for food marketing). Also excluded were studies examining unhealthy products marketed to children where food is only one category of products (i.e., food, cigarettes, alcohol), as well as studies where food advertising is only one of multiple factors being examined as a determinant of health (e.g., alongside physical activity, nutritional value of foods, etc.). Finally, studies were excluded if they examined mass media effects on children's attitudes and behaviours where food advertising is only one of multiple topics (e.g., alongside issues of body image or tobacco smoking).

\section{Data extraction and analysis}

Abstracts were reviewed for selection by one author and two graduate students. The team extracted data for the following: study aims/objectives, study type, methods, population, food promotion platform and/or technique, country studied, and indicators of "teen-targeted" food promotion. Specifically, population was recorded in terms of both defined age range (i.e., 12-17) and/or label used for age group (i.e., teenager, adolescent, child, adult). Food promotion platform was defined as the communication channel, format or setting used to reach teenagers. Examples of platforms include television, social media, and convenience stores. Food promotion techniques was defined as the specific strategies or practices used to promote food brand or product awareness to teenagers. Examples of techniques include engagement tactics (i.e., viral marketing, info mining), and publicity tactics (i.e., philanthropic marketing, event sponsorship, etc.). Indicators refer to the criteria describing specific appeals in food marketing messages. Examples of indicators include characters or spokespersons, and themes. For the analysis, we reviewed and coded the following data categories: aims/objectives to isolate measured outcomes; population to identify variations in age ranges/labels used; food promotion platform 


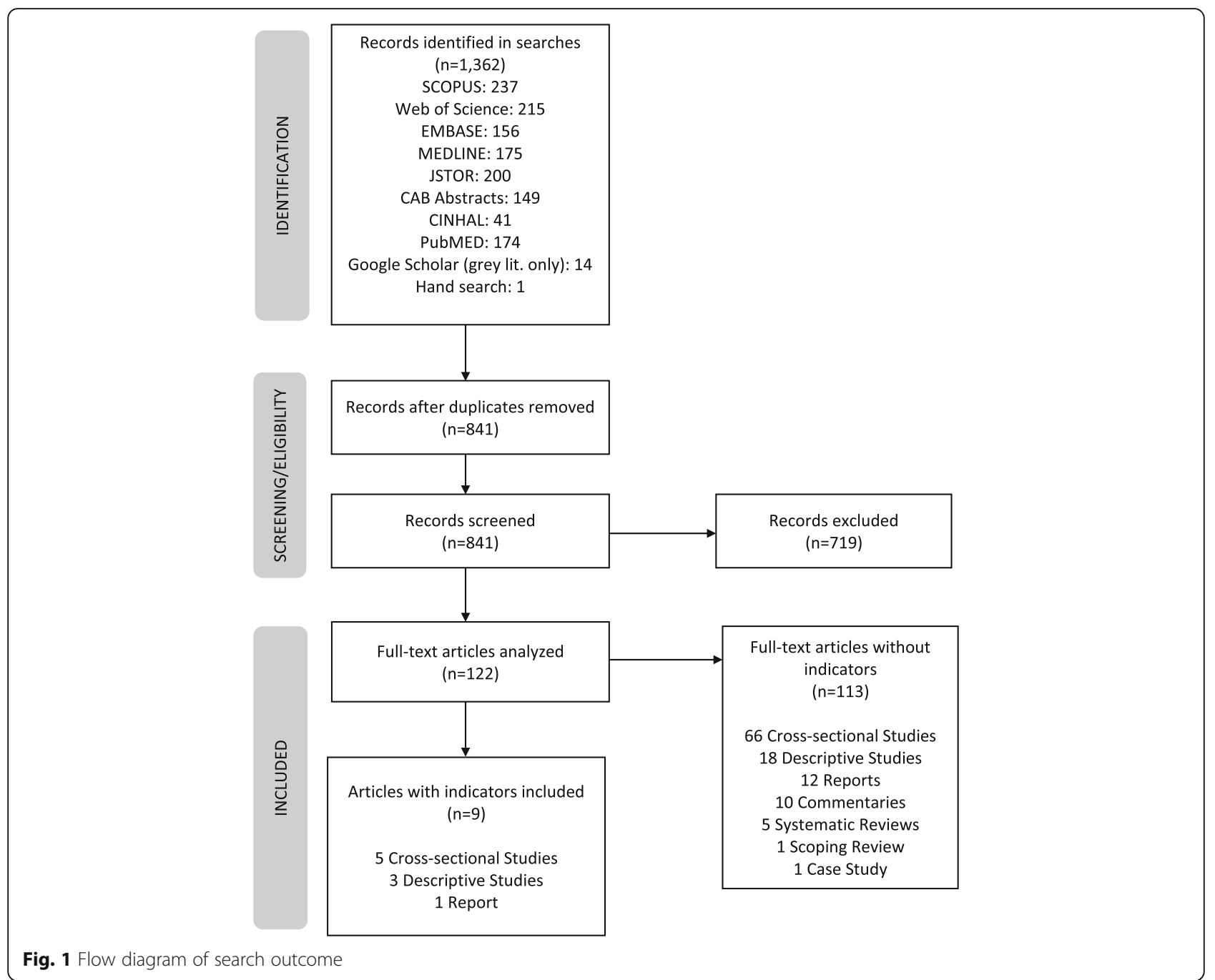

and technique to categorize research focus; and indicators to identify common themes/categories in food marketing content.

\section{Results}

We identified 841 abstracts, and marked $122[6,8,10$, $12,16,28-144]$ for inclusion in the broader study to define the scope of literature around food marketing to youth (subjects 17 and under). The identified literature dates from 1999 up until 2018, with the majority of studies appearing since 2013. Approximately half of the studies (52\%) focus on the United States: this accounts for 63 of the 122 studies. The second and third ranked entries (Australia, $n=12$; New Zealand, $n=10$ ) represent only 10 and $8 \%$ of the total, respectively. The remaining studies come from the following countries/territories: Europe $(n=5)$, multiple countries worldwide $(n=5)$, Canada $(n=4)$, India $(n=3)$, South Korea $(n=3)$, United Kingdom $(n=3)$, China $(n=2)$, Chile $(n=1)$, Germany $(n=1)$, Italy $(n=1)$, Malaysia $(n=1)$, Malta $(n=1)$,
Mexico $(n=1)$, Norway $(n=1)$, Poland $(n=1)$, Portugal $(n=1)$, Singapore $(n=1)$, Slovenia $(n=1)$, and Spain $(n=1)$.

\section{Populations identified}

Studies focusing exclusively on teenagers (ages 12-17) represent only $18 \%$ of the literature identified. Instead, research more commonly examines child and teenage populations concurrently (36\%), or includes teenager age ranges under the label of "child" (30\%). With much less frequency, teenagers are examined concurrently with children and adults (7\%), adults (5\%), and as "children" alongside adults (3\%).

\section{Outcomes and study approaches}

The majority of outcomes measured belong to the category of advertising/media exposure (54\%), with much smaller numbers of studies identified in relation to behaviours $(13 \%)$, attitudes $(11 \%)$, obesity $(7 \%)$. Nineteen percent of the studies were reviews, reports and 
commentaries without measurable outcomes. In terms of study type, the majority of studies are cross-sectional (58\%), while content analysis is the most frequently used method (46\%).

\section{Marketing/promotions identified}

Included studies described a variety of communication channels (or platforms) through which teen-targeted food marketing was delivered. These promotion platforms were grouped into three broad categories: 1) broadcast/mass media (i.e., television, radio, magazines, movies, sign/poster, billboards, food packaging); 2) digital (i.e., website, banner ads, smartphones, social media, video games, YouTube, mobile app); and 3) settings-based (i.e., schools, movie theatre, fast food restaurant, grocery store, convenience store, public transit, sports club). Broadcast/mass media accounted for 59\% of platforms examined in existing studies, followed by digital at $25 \%$ and settings-based at $16 \%$.

Numerous promotion techniques were described, and grouped into ten categories. Techniques included: 1) ad content/style (i.e., licensed/branded character, animation/sound effects); 2) brand familiarity (i.e., product placement, endorsers/influences); 3) digital engagement tactics (i.e., viral marketing, accounts/memberships and info mining); 4) events and publicity (i.e., philanthropic marketing, publicity); 5) games and play (i.e., advergames, quizzes/polls); 6) general engagement tactics (i.e., integrated or direct marketing, advertorials); 7) incentives (i.e., giveaways, coupons/rebates); 8) product elements (i.e., product design, appeals/claims); 9) settings-based tactics (i.e., retail/point-of-purchase displays, product sales in schools); and 10) sponsorship (i.e., celebrity endorsement, sports event sponsorship).

\section{Teen-specific marketing appeals}

Of the 122 included studies, only 9 specified criteria, or indicators, to identify defining aspects of teen-targeted food marketing. Collectively, they offer a list of 42 indicators that describe the content of teen food advertising from characters and celebrities, to actors/models, to themes and activities. These studies and their indicators are reported in Table 1.

The indicators reported in Table 1 were then summarized into 12 categories to represent different aspects of marketing content targeting teens. These indicator categories are: teen actors, teen themes, teen media, teen products, teen incentives, celebrities that appeal to teens, teen activities, animated characters, teen language, "fun", teen humour, and teen music. The reported frequencies of these categories across the studies identified are represented in Fig. 2. As illustrated, a wide variety of indicators are in use across a small number of studies (7\%), while the vast majority of literature uses no indicators at all to identify teen-specific food marketing content (93\%).

\section{Discussion}

This study highlights that there are very few food marketing studies that focus exclusively on teenage populations, despite this group being highly targeted and vulnerable to promotional appeals $[1,7,11]$. The problem with examining teens alongside, or as part of the larger group of, child populations is that teen-specific marketing appeals are rarely differentiated from childfocused ones. This presents challenges in terms of identifying and accurately measuring the presence of teen food promotion. Indeed, in existing literature, such content is often passively identified by selecting a promotional platform that targets teenagers (e.g., a television channel), and then performing a content analysis of its advertisements. In such studies, the main outcome being measured is exposure level to food marketing (i.e., number of commercials within a given time frame), with limited attention to the actual content of those messages. The assumption is that, based on the platform, the advertisements will by default appeal to teenagers.

As this scoping review reveals, television advertising remains the primary focus of literature on youth food marketing: $40 \%$ of the included studies focus exclusively on television programming, and $66 \%$ overall include television as an object of study (as the main focus, or in addition to other platforms). This emphasis on television in existing food marketing studies on youth means that other platforms (e.g.., digital, settings-based), which represent important sources of teen-targeted messaging, are less understood. Indeed, the World Health Organization has identified regulatory focus on broadcast advertising as a key challenge to implementing policy on food marketing to young people because it ignores the digital sphere (as well as sponsorship and product packaging) [7]. Settings-based marketing also requires more attention: a recent scoping review found that exposure levels for children under age 17 in Canada are potentially underestimated, as they are marketed to in their homes, schools, and supermarkets [10].

The existing focus on television programming also excludes the range of promotion techniques now used to market food and beverages to youth [3]. We define promotion techniques as specific strategies used to promote brand awareness to youth, as opposed to promotion platforms which are the communication channels used to reach them. In the literature identified, promotion platforms and techniques were often conflated. This is problematic because the former is simply a delivery mechanism, while the latter is a targeted strategy or practice. Stated differently, food marketing platforms can be used to measure exposure to advertising, but the 
Table 1 Summary of studies reporting indicators to identify teen-targeted food marketing

\begin{tabular}{|c|c|c|}
\hline Study & Teen Population & Indicators of teen-targeted food/beverage marketing \\
\hline Federal Trade Commission (2008) [59] & $12-17$ year olds & $\begin{array}{l}\text {-animated or licensed characters } \\
\text {-popular celebrities } \\
\text {-language of 'teen/teenager/adolescent' } \\
\text {-teenaged performers/models/characters } \\
\text {-teen themes/activities/incentives/products/media } \\
\text { (Appendix B, attachment C: p. C3, C13) }\end{array}$ \\
\hline Harris et al. (2010) [79] & $\begin{array}{l}17 \text { and under (classified as } \\
\text { "general audience") }\end{array}$ & $\begin{array}{l}\text {-product or personality from TV (general audience), PG-13 } \\
\text { movie, or other type of entertainment, or sports, or product } \\
\text { (p. 411) }\end{array}$ \\
\hline Harris et al. (2011) [81] & 12-17 year olds & $\begin{array}{l}\text {-'placed to reach teens' } \\
\text { - teenaged main characters (also targeting race/ethnicity) } \\
\text { - addresses teen directly } \\
\text { - promotes teen products } \\
\text { - uses techniques appealing to teens (i.e., social media) } \\
\text { (p. 114) }\end{array}$ \\
\hline Potvin Kent et al. (2011) [113] & 10-12 year olds & $\begin{array}{l}\text {-'fun' (i.e. product has playful shape, colour, taste, and/or depiction } \\
\text { of interactions with the product in ad show high levels of enjoyment) } \\
\text {-media characters or celebrities (i.e., licensed characters, and sport, } \\
\text { TV, movie, and music celebrities) } \\
\text { (p. e435) }\end{array}$ \\
\hline $\begin{array}{l}\text { Interagency Working Group on Food } \\
\text { Marketing to Children (2011) [85] }\end{array}$ & 12-17 year olds & $\begin{array}{l}\text {-animated or licensed characters } \\
\text {-teen language } \\
\text {-teenaged models } \\
\text {-teen themes/activities/incentives } \\
\text {-appeal to teens to participate in promotion } \\
\text { (p. 19) }\end{array}$ \\
\hline Federal Trade Commission (2012) [60] & 12-17 year olds & $\begin{array}{l}\text {-animated or licensed characters } \\
\text {-popular celebrities } \\
\text {-language of 'teen/teenager/adolescent' } \\
\text {-teenaged performs/models/characters } \\
\text {-teen themes/activities/incentives/products/media } \\
\text { (Appendix B, attachment C: p. C3, C13) }\end{array}$ \\
\hline Potvin Kent et al. (2014) [114] & 12-17 year olds & $\begin{array}{l}\text {-characters that teens identify with } \\
\text {-adolescent activities (i.e., school dances, video games) } \\
\text {-teen music } \\
\text {-adolescent themes (i.e., popularity, freedom) } \\
\text {-teen humour } \\
\text { (p. 2055) }\end{array}$ \\
\hline Théodore et al. (2017) [133] & 15-18year olds & $\begin{array}{l}\text {-adolescent characters } \\
\text {-adolescent context/themes (i.e., high schools, concerts) } \\
\text { (p. 314) }\end{array}$ \\
\hline Vandevijvere et al. (2017) [137] & 13-17 year olds & $\begin{array}{l}\text {-adolescent themes (i.e., fashion, image, sexuality) } \\
\text { (p. 34) }\end{array}$ \\
\hline
\end{tabular}

power of that advertising is more accurately assessed by examining the content of promotion techniques [145].

This study identified a remarkable variety of promotion techniques in use to target young people (17 and under): 78 unique items were grouped into the ten categories (described in the results section), ranging from settings-based and digital tactics, to more traditional approaches such as brand familiarity and sponsorship/endorsements. When it comes to teen food marketing, promotion techniques are significant as teenagers may be targeted by specialized techniques that do not reach younger children. For example, consider information gathering/info mining or incentives that are the result of signing up for subscriptions or accounts for registered users over the age of 13; point- of-purchase displays in stores where teenagers use their own spending money; viral marketing and/or word-ofmouth marketing (which may be significant due to the importance of peer acceptance), and the social/symbolic value of food (brands, or 'cool' food products) within the peer group [146, 147]. However, the content of these targeted messages, not simply the type of strategy, matters as well. It is critical to identify marketing content that appeals to teens in order to better understand its potential impacts. For instance, when it comes to "special offer" promotions, are teens incentivized by coupons or by limited-edition products? Which tactic is more likely to influence their food preferences and/or motivate their purchase behaviours? 


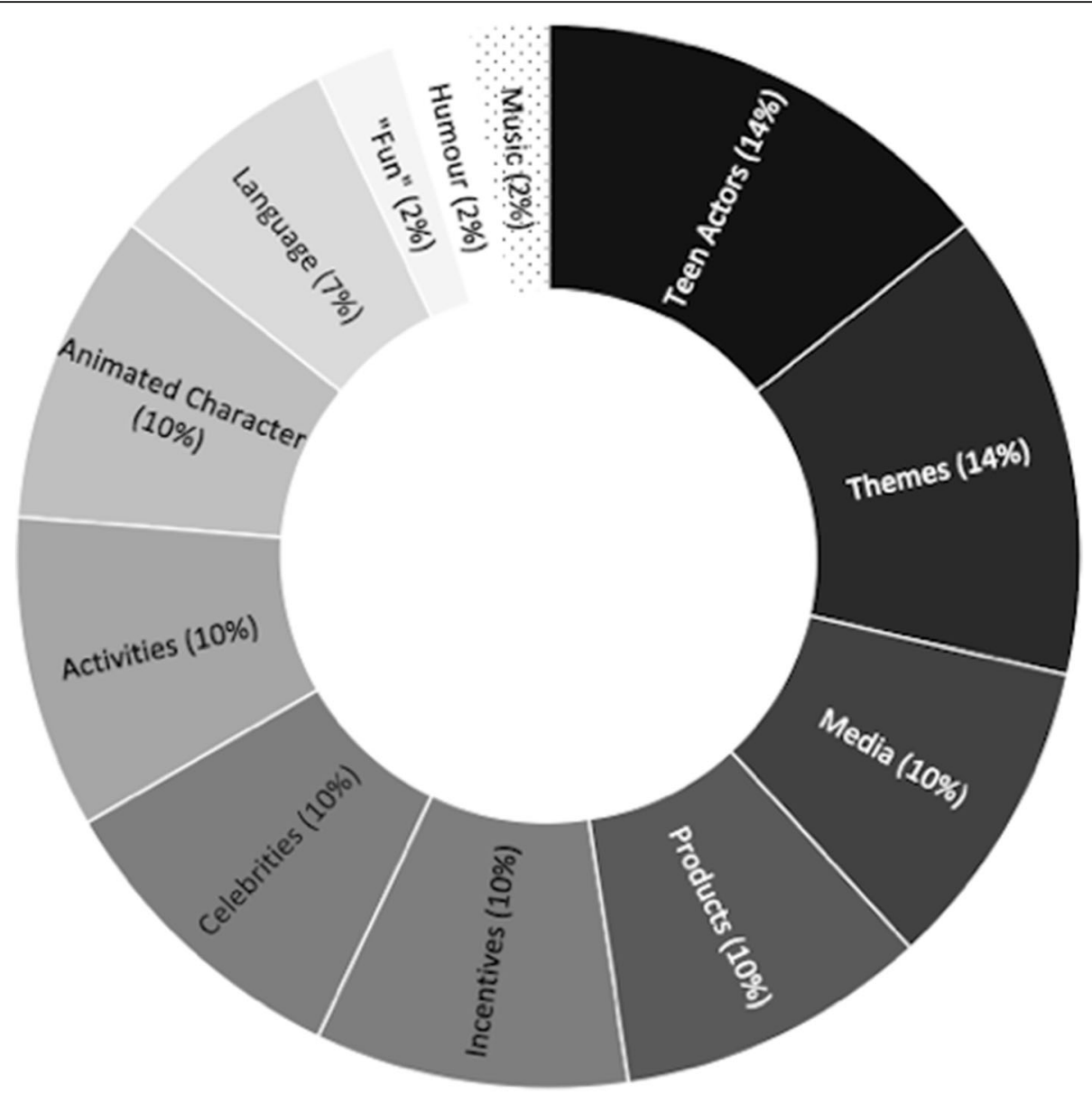

Fig. 2 Indicators of teen-targeted food marketing, by frequency across nine studies

The need for improved understanding of the content of teen-targeted food marketing is particularly acute in the Canadian context, where Health Canada is preparing to implement Bill S-228, the Child Health Protection Act, which will prohibit the marketing of unhealthy food and beverages to children under age 13 [26]. As part of this initiative, Health Canada has committed to monitor the marketing of unhealthy foods to teenagers aged 1317, in order to assess whether food and beverage marketing to teenagers will increase post-legislation. Additionally, the World Health Organization has identified the need for worldwide monitoring of digital marketing to children under 17 , in light of the increasing popularity of social media/mobile devices for this age group which involves targeted/personalized advertising [148]. Monitoring depends not only upon the ability to accurately identify where and when food marketing reaches teens, but also how it appeals to them, and the use of indicators is critical to this process. The indicators identified in this study are a good starting point for considering how teen-targeted marketing appeals are specific to that age group. However, some indicators are clearer than others for determining inclusion/exclusion. For example, the presence of a teenaged actor or animated character counts as teen-targeted, as does language that directly addresses the teen audience (i.e., the terms "teen", "teenager", "adolescent"). These are straightforward to identify. The following categories are less clear: teen theme, teen activity, celebrities that appeal to teens, teen incentives, teen humour, and teen music. Specific definitions are needed for each of these categories so that the interpretation of these terms is not reliant on the subjective opinions of researchers or policy makers. Finally, several of the indicators identified in existing literature are completely unclear as inclusion criteria: does the category of "media" refer to the platform used to reach teens, or the use of teen media as a theme (i.e., image of a smartphone in the advertising)?; does "product" refer to ones made-for-teens, or to any products that teens find appealing?; and where the indicator "fun" refers to a product and its representation in advertisements, is this characteristic valued by teen audiences, or are they perhaps more concerned with "cool/ trendy"? Additional qualitative research is needed to 
determine how teens themselves describe and define food marketing directed at them, in order to properly differentiate between teen-specific, child, and adult oriented content, and to inform conceptions of teen indicators.

It is important to note a limitation of this review: the summary of indicators is based on a small number of identified studies, and their validity needs to be tested in future research. Studies that focus exclusively on the $12-17$ year old age range are needed in order to examine the uniqueness of teen appeals. Nuanced research in this area will provide much needed insight into the power of teenager-targeted food marketing, and its potential impacts on food attitudes and behaviours.

\section{Conclusions}

Food and beverage marketing to teenagers is ubiquitous. However, little focused research exists on teenage populations, despite their vulnerability. The most commonly measured outcome in studies of food marketing to young people (17 and under) is exposure to advertising-and most often in television programming-which ignores the increasing range of promotion platforms and techniques specifically targeting teenagers. More research is needed to identify teen-specific food marketing content, and this scoping review is the first to analyze the specific indicators currently being used for evaluating such appeals. The ability to isolate teen-targeted food and beverage marketing will allow for more effective monitoring of its presence, and assessment of its power and potential impacts on teenagers, in order to inform policy around its regulation.

\section{Acknowledgements}

CE would like to acknowledge funding support from the Canada Research Chair Program.

\section{Authors' contributions}

CE conceived and designed the study. ET carried out the study, including data collection and analysis. ET drafted the manuscript. CE reviewed the manuscript and provided feedback and edits. Both authors reviewed and approved the final content.

\section{Availability of data and materials}

Not applicable

\section{Ethics approval and consent to participate}

Not applicable

\section{Consent for publication}

Not applicable

\section{Competing interests}

The authors declare that they have no competing interests.

Received: 27 March 2019 Accepted: 13 August 2019

Published online: 19 August 2019

\section{References}

1. Harris J, Heard A, Schwartz M. Older but still vulnerable: all children need protection from unhealthy food marketing. Yale Rudd Center for Food
Policy \& Obesity. 2014; www.uconnruddcenter.org/files/Pdfs/Protecting_ Older_Children_3_14.pdf.

2. Casey BJ, Jones RM, Hare TA. The adolescent brain. Ann N Y Acad Sci. 2008; 1124:111-26.

3. Knoll L, Magis-Weinberg L, Speekenbrink M, Blakemore S. Social influence on risk perception during adolescence. Psychol Sci. 2015;26(5):583-92.

4. Albert D, Chein J, Steinberg L. The teenage brain: peer influences on adolescent decision making. Curr Dir Psychol Sci. 2013;22(2):114-20.

5. Steinberg $L$, Monahan KC. Age differences in resistance to peer influence. Dev Psychol. 2007:43(6):1531-43.

6. World Health Organization. Tackling food marketing to children in a digital world: transdisciplinary perspectives. Denmark: World Health Organization; 2016.

7. World Health Organization. Evaluating implementation of the WHO set of recommendations on the marketing of food and non-alcoholic beverages to children: Progress, challenges and guidance for next steps in the WHO European region. Denmark: World Health Organization Regional Office for Europe; 2018.

8. World Health Organization. Marketing of food high in fat, salt and sugar to children: update 2012-2013. Denmark: The Regional Office for Europe of the World Health Organization; 2013.

9. Heart \& Stroke Foundation. The kids are not alright: How the food and beverage industry is marketing our children and youth to death. Ottawa: Heart \& Stroke Foundation; 2017.

10. Prowse R. Food marketing to children in Canada: A settings-based scoping review on exposure, power and impact. Health Promot Chronic Dis Prev Can. 2017. https://doi.org/10.24095/hpcdp.37.9.03.

11. Elliott C. "Grab Gatorade!": food marketing, regulation and the young consumer. Eur J Mark. 2018. https://doi.org/10.1108/EJM-05-2018-0355.

12. Norman J, Kelly B, Boyland E, McMahon A. The impact of marketing and advertising on food behaviours: evaluating the evidence for a causal relationship. Curr Nutr Rep. 2016. https://doi.org/10.1007/s13668-016-0166-6.

13. Jenkin G, Madhvani N, Signal L, Bowers S. A systematic review of persuasive marketing techniques to promote food to children on television. Obes Rev. 2013;15:281-93.

14. Kraak VI, Story M. Influence of food companies' brand mascots and entertainment companies' cartoon media characters on children's diet and health: a systematic review and research needs. Obes Rev. 2015;16:107-26.

15. Hebden L, King L, Kelly B, Chapman K, Innes-Hughes C. A menagerie of promotional characters: promoting food to children through food packaging. J Nutr Educ Behav. 2011;43(5):349-55.

16. Castonguay J, Kunkel D, Wright P, Duff C. Health characters? An investigation of marketing practices in children's food advertising. J Nutr Educ Behav. 2013. https://doi.org/10.1016/j.jneb.2013.03.007.

17. Kelly B, Hattersley L, King L, Flood V. Persuasive food marketing to children: use of cartoons and competitions in Australian commercial television advertisements. Health Promot Int. 2008;23(4):337-44.

18. Neeley SM, Schumann DW. Using animated spokes-characters in advertising to young children. J Advert. 2004;33(3):7-33.

19. Ogle AD, Graham DJ, Lucas-Thompson RG, Roberto CA. Influence of cartoon media characters on children's attention to and preference for food and beverage products. J Acad Nutr Diet. 2017;117:265-70.

20. Boyland EJ, Harrold JA, Dovey TM, Allison M, Dobson S, Jacobs M, Halford JCG. Food choice and overconsumption: effect of a premium sports celebrity endorser. J Pediatr. 2013;163:339-43.

21. McGale LS, Halford JCG, Harrold JA, Boyland EJ. The influence of brand equity characters on children's food preferences and choices. J Pediatr. 2013;177:33-8.

22. Roberto CA, Baik J, Harris JL, Brownell KD. Influence of licensed characters on children's taste and snack preferences. J Pediatr. 2010;126:88-93.

23. Elliott C. Assessing fun foods: nutritional content and analysis of supermarket foods targeted at children. Obes Rev. 2008;9:368-77.

24. Elliott C. Packaging fun: Analysing supermarket food messages targeted at children. Canadian J Comm. 2012;37(2):303-18.

25. World Cancer Research Fund International. NOURISHING framework: restrict food advertising and other forms of commercial promotion. London: World Cancer Research Fund International; 2019. https://www.wcrf.org/sites/ default/files/4_Restrict\%20advertising_May2019.pdf

26. Bill S-228: An Act to amend the Food and Drugs Act (prohibiting food and beverage marketing directed at children) [short title: Child Health Protection Act]. 3rd Reading, September 19, 2018, 42nd parliament, 1st session, 
December 3, 2015 - present. Ottawa: Public Works and Government Services Canada, 2018

27. Haddaway NR, Collins AM, Coughlin D, Kirk S. The role of Google Scholar in evidence reviews and its applicability to grey literature searching. PLoS One. 2015;10(9):e0138237.

28. Adachi-Mejia AM, Sutherland LA, Longacre MR, Beach ML, Titus-Ernstoff L, Gibson JJ, Dalton MA. Adolescent weight status and receptivity to food TV advertisements. J Nutr Educ Behav. 2011;43(6):441-8.

29. Beaudoin CE. The mass media and adolescent socialization: a prospective study in the context of unhealthy food advertising. J Mass Commun Q. 2014. https://doi.org/10.1177/1077699014538829.

30. Berning J, Rabinowitz AN. Targeted advertising in the breakfast cereal industry. Am J Agric Econ. 2017. https://doi.org/10.1017/aae.2017.1.

31. Bibeau WS, Saksvig BI, Gittelsohn J, Williams S, Jones L, Young DR. Perceptions of the food marketing environment among African American teen girls and adults. Appetite. 2012. https://doi.org/10.1016/j.appet.2011.11.004.

32. Boyland E, Harrold JA, Kirkham TC, Halford JCG. Persuasive techniques used in television advertisements to market foods to UK children. Appetite. 2012. https://doi.org/10.1016/j.appet.2011.11.017

33. Boyland E, Harrold JA, Kirkham TC, Halford JCG. The extent of food advertising to children on UK television in 2008. Pediatr Obes. 2011. https:// doi.org/10.3109/17477166.2011.608801.

34. Boyland E, Tatlow-Golden M. Exposure, power and impact of food marketing on children: evidence supports strong restrictions. Eur J Risk Regul. 2017. https://doi.org/10.1017/err.2017.21.

35. Bragg MA, Miller AN, Elizee J, Dighe S, Elbel BD. Popular music celebrity endorsements in food and non-alcoholic beverage marketing. Pediatrics. 2016. https://doi.org/10.1542/peds.2015-3977.

36. XBragg MA, Liu PJ, Roberto CA, Sarda V, Harris JL, Brownell KD. The use of sports references in marketing of food and beverage products in supermarkets. Public Health Nutr. 2012. https://doi.org/10.1017/s136 8980012003163

37. Bragg MA, Roberto CA, Harris JL, Brownell KD, Elbel B. Marketing food and beverages to youth through sports. J Adolesc Health. 2018. https://doi.org/1 0.1016/j.jadohealth.2017.06.016.

38. Breiner $\mathrm{H}$, Parker $\mathrm{L}$, Olson S. In: Montgomery K, editor. Challenges and opportunities for change in food marketing to children and youth: Workshop summary. Part 3 - Marketing to Adolescents. Washington: D.C: Institute of Medicine; 2013. p. 17-20.

39. Bruce AS, Bruce JM, Black WR, Lepping RJ, Henry JM, Cherry JBC, et al. Branding and a child's brain: An fMRI study of neural responses to logos. Soc Cogn Affect Neurosci. 2014. https://doi.org/10.1093/scan/nss 109.

40. Bruce AS, Pruitt SW, Ha O, Cherry JB, Smith TR, Bruce JM, Lim S. The influence of televised food commercials on children's food choices: evidence from ventromedial prefrontal cortex activations. Pediatrics. 2016. https://doi.org/10.1016/j.jpeds.2016.06.067.

41. Bugge AB. Food advertising towards children and young people in Norway. Appetite. 2016. https://doi.org/10.1016/j.appet.2015.12.008.

42. Burger KS, Stice E. Neural responsivity during soft drink intake, anticipation, and advertisement exposure in habitually consuming youth. Obes. 2014; 22(2):441-50.

43. Calvert SL. Children as consumers: advertising and marketing. Futur Child. 2008. https://doi.org/10.1353/foc.0.0001.

44. Campos D, Hernandez-Torres JJ, Agil A, Comino M, Lopez JC, Maclas V, Campoy C. Analysis of food advertising to children on Spanish television: probing exposure to television marketing. Arch Med Sci. 2016. https://doi. org/10.5114/aoms.2016.60969.

45. Cauchi D, Reiff S, Knai C, Gauci C, Spiteri J. Television food advertising to children in Malta. Health Promot Int. 2017. https://doi.org/10.1093/heapro/dav105.

46. Cervi MM, Agurs-Collins T, Dwyer LA, Thai CL, Moser RP, Nebeling LC. Susceptibility to food advertisements and sugar-sweetened beverage intake in non-Hispanic black and non-Hispanic white adolescents. J Community Health Res. 2017. https://doi.org/10.1007/s10900-016-0313-4.

47. Chester J, Montgomery K. Interactive food and beverage marketing: targeting adolescents in the digital age. J Adolesc Health. 2009. https://doi. org/10.1016/j.jadohealth.2009.04.006.

48. Cheyne A, Mejia P, Nixon L, Dorfman L. Food and beverage marketing to youth. Curr Obes Rep. 2014. https://doi.org/10.1007/s13679-014-0122y.

49. Cheyne A, Dorfman L, Bukofzer E, Harris JL. Marketing sugary cereals to children in the digital age: a content analysis of 17 child-targeted websites. J Health Commun. 2013. https://doi.org/10.1080/10810730.2012.743622.
50. Chou S-Y, Rashad I, Grossman M. Fast-food restaurant advertising on television and its influence on childhood obesity. J Law Econ. 2008. https:// doi.org/10.1086/590132.

51. Cowburn G, Boxer A. Magazines for children and young people and the links to internet food marketing: a review of the extent and type of food advertising. Public Health Nutr. 2007. https://doi.org/10.1017/S136 8980007666658

52. Dietz WH. New strategies to improve food marketing to children. Health Aff (Millwood). 2013. https://doi.org/10.1377/hlthaff.2012.1294.

53. Disantis KI, Kumanyika S, Carter-Edwards L, Young DR, Grier SA, Lassiter V. Sensitizing black adult and youth consumers to targeted food marketing tactics in their environments. Int J Environ Res Public Health. 2017. https:// doi.org/10.3390/ijerph14111316.

54. Dority B, McGarvey M, Kennedy P. Marketing foods and beverages in schools: the effect of school food policy on students' overweight measures. J Public Policy Mark. 2010;29(2):204-18.

55. Effertz T, Wilcke A. Do television food commercials target children in Germany? Public Health Nutr. 2012. https://doi.org/10.1017/S1368980011003223.

56. Elliott C. Knowledge needs and the 'savvy' child: teenager perspectives on banning food marketing to children. Crit Public Health. 2017. https://doi. org/10.1080/09581596.2016.1240356.

57. Elsey JW, Harris JL. Trends in food and beverage television brand appearances viewed by children and adolescents from 2009 to 2014 in the USA. Public Health Nutr. 2015. https://doi.org/10.1017/s1368980015003274.

58. European Commission. Food and non-alcoholic beverage marketing to children and adolescents. London: European Commission- Joint Research Center; 2017.

59. Federal Trade Commission. Marketing food to children and adolescents: A review of industry expenditures, activities, and self-regulation. Washington: U.S: Federal Trade Commission; 2008.

60. Federal Trade Commission. A review of food marketing to children and adolescents: follow-up report. Washington: U.S: Federal Trade Commission; 2012.

61. Fleming-Milici F, Harris JL. Television food advertising viewed by preschoolers, children and adolescents: contributors to differences in exposure for black and white youth in the United States. Pediatr Obes. 2018. https://doi.org/10.1111/ijpo.12203.

62. Freeman B, Kelly B, Baur L, Chapman K, Chapman S, Gill T, King L. Digital junk: food and beverage marketing on Facebook. Am J Public Health Res. 2014. https://doi.org/10.2105/AJPH.2014.302167.

63. Gantz W, Schwartz N, Angelini J, Rideout V. Food for thought: television food advertising to children in the United States. Henry J. Kaiser Family Foundation: Menlo Park; 2007.

64. Galbraith-Emami S, Lobstein T. The impact of initiatives to limit the advertising of food and beverage products to children: a systematic review. Obes Rev. 2013. https://doi.org/10.1111/obr.12060.

65. Gearhardt AN, Yokum S, Stice E, Harris JL, Brownell KD. Relation of obesity to neural activation in response to food commercials. Soc Cogn Affect Neurosci. 2014. https://doi.org/10.1093/scan/nst059.

66. Gebauer H, Laska MN. Convenience stores surrounding urban schools: an assessment of healthy food availability, advertising and product placement. J Urban Health. 2011. https://doi.org/10.1007/s11524-011-9576-3.

67. Giese H, König LM, Tăut D, Ollila H, Băban A, Absetz P, et al. Exploring the association between television advertising of healthy and unhealthy foods, self-control, and food intake in three European countries. Appl Psychol Health Well Being. 2015. https://doi.org/10.1111/aphw.12036.

68. Gregori D, Ballali S, Vecchio MG, Sciré AS, Foltran F, Berchialla P. Randomized controlled trials evaluating effect of television advertising on food intake in children: why such a sensitive topic is lacking toplevel evidence? Ecol Food Nutr. 2014. https://doi.org/10.1080/03670244.2 014.883976

69. Grigsby-Toussaint DS, Moise IK, Geiger SD. Observations of marketing on food packaging targeted to youth in retail food stores. Obesity. 2011. https://doi.org/10.1038/oby.2011.120.

70. Goldberg ME, Gunasti K. Creating an environment in which youths are encouraged to eat a healthier diet. J Public Policy Mark. 2007. https://doi. org/10.1509/jppm.26.2.162.

71. Grossman M, Tekin E, Wada R. Fast-food restaurant advertising on television and on youth body composition. NBER Working Paper No. 18640. 2012.

72. Gupta S, Kalra S, Kaushik J, Gupta P. Content of food advertising for young adolescents on television. Indian J Community Med. 2017. https://doi.org/1 0.4103/0970-0218.199800. 
73. Hammond KM, Wyllie A, Casswell S. The extent and nature of televised food advertising to New Zealand children and adolescents. Aust N Z J Public Health. 1999. https://doi.org/10.1111/j.1467-842X.1999.tb01204.x.

74. Han E, Powell LM, Kim TH. Trends in exposure to television food advertisements in South Korea. Appetite. 2013. https://doi.org/10.1016/j. appet.2012.10.015.

75. Harris $J$, Heard A, Kunkel D. Marketing unhealthy foods to children on Facebook. In: Dimofte CV, Haugtvedt CP, Yalch R, Ebrary I, editors. Consumer psychology in a social media world. New York: Routledge; 2015. p. 239-53.

76. Harris $J$, Hyary M, Schwartz MB. Effects of offering look-alike products as smart snacks in schools. Child Obes. 2016. https://doi.org/10.1089/ chi.2016.0080

77. Harris JL, Graff SK. Protecting young people from junk food advertising: implications of psychological research for first amendment law. Am J Public Health Res. 2012. https://doi.org/10.2105/AJPH.2011.300328.

78. Harris JL, Lodolce M, Dembek C, Schwartz MB. Sweet promises: candy advertising to children and implications for industry self-regulation. Appetite. 2015. https://doi.org/10.1016/j.appet.2015.07.028.

79. Harris JL, Schwartz MB, Brownell KD. Marketing foods to children and adolescents: licensed characters and other promotions on packaged foods in the supermarket. Public Health Nutr. 2010. https://doi.org/10.1017/S136 8980009991339.

80. Harris JL, Schwartz MB, Brownell KD. Evaluating fast food nutrition and marketing to youth. New Haven: Yale Rudd Center for Food Policy \& Obesity; 2010

81. Harris JL, Schwartz MB, Brownell KD, Javadizadeh J, Weinberg M. Evaluating sugary drink nutrition and marketing to youth. New Haven: Yale Rudd Center for Food Policy \& Obesity; 2011.

82. Heredia AM, Hipolito J, Nunes O, Ribeiro L, Moura T, Laneiro T. Fast-food marketing strategies and their impact on childhood obesity. J Spa Organ Dyn. 2017;5(3):296-315

83. Herrera AL, Pasch KE. Targeting Hispanic adolescents with outdoor food \& beverage advertising around schools. Ethn Health. 2018. https://doi.org/10.1 080/13557858.2017.1290217.

84. Hingle MD, Castonguay JS, Ambuel DA, Smith RM, Kunkel D. Alignment of children's food advertising with proposed federal guidelines. Am J Prev Med. 2015. https://doi.org/10.1016/j.amepre.2015.01.004.

85. Interagency Working Group on Food Marketing to Children (FTC, CDC, FDA USDA). Interagency working group on food marketed to children: Preliminary proposed nutrition principles to guide industry self-regulatory efforts. Washington: FTC, CDC, FDA, \& USDA; 2011.

86. Jackson $M$, Harrison $P$, Swinburn B, Lawrence M. Unhealthy food, integrated marketing communication and power: a critical analysis. Crit Public Health. 2014. https://doi.org/10.1080/09581596.2013.878454.

87. Jones SC, Kervin L. An experimental study on the effects of exposure to magazine advertising on children's food choices. Public Health Nutr. 2011. https://doi.org/10.1017/S1368980010002983.

88. Jones SC, Mannino N, Green J. Like me, want me, buy me, eat me: relationship-building marketing communications in children's magazines. Public Health Nutr. 2010. https://doi.org/10.1017/S1368980010000455.

89. Kelly B, Baur LA, Bauman AE, King L, Chapman K, Smith BJ. "Food company sponsors are kind, generous and cool": (Mis)conceptions of junior sports players. Int J Behav Nutr Phys Act. 2011. https://doi.org/1 0.1186/1479-5868-8-95.

90. Kelly B, Freeman B, King L, Chapman K, Baur LA, Gill T. The normative power of food promotions: Australian children's attachments to unhealthy food brands. Public Health Nutr. 2016. https://doi.org/10.101 7/S1368980016001452

91. Kelly B, Smith B, King L, Flood V, Bauman A. Television food advertising to children: the extent and nature of exposure. Public Health Nutr. 2007. https://doi.org/10.1017/\$1368980007687126.

92. Korošec Ž, Pravst I. Television food advertising to children in Slovenia: analyses using a large 12-month advertising dataset. Int J Public Health Res. 2016. https://doi.org/10.1007/s00038-016-0896-7.

93. Kumar G, Zytnick D, Onufrak S, Harris JL, Wethington H, Kingsley B, Park SH. Caregiver and adolescent responses to food and beverage marketing exposures through an online survey. J Child Obes. 2014. https://doi.org/10.1 089/chi.2013.0124.

94. Lee B, Kim H, Lee S, Yoon J, Chung S. Effects of exposure to television advertising for energy-dense/nutrient-poor food on children's food intake and obesity in South Korea. Appetite. 2014. https://doi.org/10.1016/j.appet.2014.06.103.
95. Lee ST, Nguyen HL. Explicating the moral responsibility of the advertiser: TARES as an ethical model for fast food advertising. J Mass Media Ethics. 2013. https://doi.org/10.1080/08900523.2013.792700.

96. Li D, Wang T, Cheng Y, Zhang M, Yang X, Zhu Z, et al. The extent and nature of television food advertising to children in Xi'an, China. BMC Public Health. 2016. https://doi.org/10.1186/s12889-016-3468-0.

97. Linn SE. Food marketing to children in the context of a marketing maelstrom. J Public Health Policy. 2004. https://doi.org/10.1057/palgrave. jphp.3190036.

98. Maher A, Wilson N, Signal L. Advertising and availability of 'obesogenic' foods around New Zealand secondary schools: a pilot study. N Z Med J. 2005;118:1218.

99. Mazur A, Telega G, Kotowicz A, Małek H, Jarochowicz S, Gierczak B, et al. Impact of food advertising on food purchases by students in primary and secondary schools in south-eastern Poland. Public Health Nutr. 2008. https://doi.org/10.1017/S1368980008002000.

100. McClure AC, Tanski SE, Gilbert-Diamond D, Adachi-Mejia AM, Li Z, Li Z, Sargent JD. Receptivity to television fast-food restaurant marketing and obesity among U.S. youth. Am J Prev Med. 2013. https://doi.org/10.1016/j. amepre.2013.06.011.

101. McGinnis JM, Gootman JA, Kraak VI. Food marketing to children and youth: threat or opportunity? Washington: Institute of Medicine; 2006.

102. Mehta KP, Coveney J, Ward P, Handsley E. Parents' and children's perceptions of the ethics of marketing energy-dense nutrient-poor foods on the internet: implications for policy to restrict children's exposure. Public Health Ethics. 2014. https://doi.org/10.1093/phe/phu002.

103. Montgomery KC, Chester J. Interactive food and beverage marketing: targeting adolescents in the digital age. J Adolesc Health. 2009;45:S19-29.

104. Montgomery K, Grier S, Chester J, Dorman L. Food marketing in the digital age: a conceptual framework and agenda for research: Center for Digital Democracy. Berkeley: Berkeley Media Studies Group; 2011.

105. Moon YS. How food ads communicate 'health' with children: a content analysis of Korean television commercials. Asian J Commun. 2010. https:// doi.org/10.1080/01292986.2010.496858.

106. Moore ES. It's child play: Advergaming and the online marketing of food to children. Henry J. Kaiser Family Foundation: Menlo Park; 2006.

107. Neville L, Thomas M, Bauman A. Food advertising on Australian television: the extent of children's exposure. Health Promot Int. 2005. https://doi.org/1 0.1093/heapro/dah601

108. Ng SH, Kelly B, Se CH, Chinna K, Sameeha MJ, Krishnasamy S, Ismail MN, Karupaiah T. Obesogenic television food advertising to children in Malaysia: sociocultural variations. Glob Health Action. 2015. https://doi. org/10.3402/gha.v7.25169.

109. No E, Kelly B, Devi A, Swinburn B, Vandevijvere S. Food references and marketing in popular magazines for children and adolescents in New Zealand: a content analysis. Appetite. 2014. https://doi.org/10.1016/j.appet.2014.08.013.

110. Outley CW, Taddese A. A content analysis of health and physical activity messages marketed to African American children during after-school television programming. Arch Pediatr Adolesc Med. 2016;160(4):432-5.

111. Pettigrew S, Tarabashkina L, Roberts M, Quester P, Chapman K, Miller C. The effects of television and internet food advertising on parents and children. Public Health Nutr. 2013. https://doi.org/10.1017/S136 8980013001067.

112. Pomeranz JL, Munsell CR, Harris JL. Energy drinks: an emerging public health hazard for youth. J Public Health Policy. 2013. https://doi.org/10.105 7/jphp.2013.6

113. Potvin Kent M, Dubois $L$, Wanless A. Food marketing on children's television in two different policy environments. Int J Pediatr Obes. 2011. https://doi. org/10.3109/17477166.2010.526222.

114. Potvin Kent M, Martin CL, Kent EA. Changes in the volume, power and nutritional quality of foods marketed to children on television in Canada. Obesity. 2014. https://doi.org/10.1002/oby.20826.

115. Powell LM, Harris JL, Fox T. Food marketing expenditures aimed at youth: putting the numbers in context. Am J Prev Med. 2013. https://doi.org/10.1 016/j.amepre.2013.06.003.

116. Powell LM, Szczypka G, Chaloupka FJ. Adolescent exposure to food advertising on television. Am J Prev Med. 2007. https://doi.org/10.1016/j. amepre.2007.07.009.

117. Powell LM, Szczypka G, Chaloupka FJ, Braunschweig CL. Nutritional content of television food advertisements seen by children and adolescents in the United States. Pediatrics. 2007. https://doi.org/10.1542/peds.2006-3595. 
118. Powell LM, Szczypka G, Chaloupka FJ. Trends in exposure to television food advertisements among children and adolescents in the United States. Arch Pediatr Adolesc Med. 2010. https://doi.org/10.1001/archpediatrics.2010.139.

119. Powell LM, Wada R, Khan T, Emery SL. Viewpoint: food and beverage television advertising exposure and youth consumption, body mass index and adiposity outcomes. Can J Econ. 2017. https://doi.org/1 $0.1111 /$ caje.12261

120. Powell LM, Wada R, Kumanyika SK. Racial/ethnic and income disparities in child and adolescent exposure to food and beverage television ads across the U.S. media markets. Health Place. 2014. https://doi.org/10.1016/j. healthplace.2014.06.006

121. Puggelli FR, Bertolotti M. Healthy and unhealthy food in Italian television ads for adults and children. Young Consum. 2014. https://doi.org/10.1108/ YC-03-2013-00364

122. Russell CA, Buhrau D. The role of television viewing and direct experience in predicting adolescents' beliefs about the health risks of fast-food consumption. Appetite. 2015. https://doi.org/10.1016/j.appet.2015.05.023.

123. Schwartz MB, Ross C, Harris JL, Jerigan DH, Siegel M, Ostroff J, Brownnell KD. Breakfast cereal industry pledges to self-regulate advertising to youth: will they improve the marketing landscape? J Public Health Policy. 2010. https:// doi.org/10.1057/jphp.2009.50

124. Scully M, Wakefield M, Niven P, Chapman K, Crawford D, Pratt IS, Baur LA, Flood V, Morley B. Association between food marketing exposure and adolescents' food choices eating behaviours. Appetite. 2012. https://doi. org/10.1016/j.appet.2011.09.020

125. Signal LN, Stanley J, Smith M, Barr MB, Chambers TJ, Zhou J, et al. Children's everyday exposure to food marketing: an objective analysis using wearable cameras. Int J Behav Nutr Phys Act. 2017. https://doi. org/10.1186/s12966-017-0570-3.

126. Sivathanu B. Food marketing and its impact on adolescents' food choices. J Mark. 2017. https://doi.org/10.17010/ijom/2017/v47/i8/117432.

127. Skatrud-Mickelson M, Adachi-Mejia AM, MacKenzie TA, Sutherland LA. Giving the wrong impression: Food and beverage brand impressions delivered to youth through popular movies. J Public Health. 2011. https:// doi.org/10.1093/pubmed/fdr089.

128. Speers SE, Harris JL, Schwartz MB. Child and adolescent exposure to food and beverage brand appearances during prime-time television programming. Am J Prev Med. 2011. https://doi.org/10.1016/j.amepre.2 011.04 .018$.

129. Staiano AE, Calvert SL. Digital gaming and pediatric obesity: at the intersection of science and social policy. Soc Issues Policy Rev. 2012. https:// doi.org/10.1111/j.1751-2409.2011.01035.x.

130. Stigler MH, Medina J, Arora M, Nazar G, Rodrigues LM, Reddy KS, Perry CL. Adolescents' response to food marketing in Delhi, India. In: Advances in communication research to reduce childhood obesity; 2013. https://doi. org/10.1007/978-1-4614-5511-0.

131. Story M, French S. Food advertising and marketing directed at children and adolescents in the US. Int J Behav Nutr Phys Act. 2004. https://doi.org/10.11 86/1479-5868-1-3.

132. Swinburn B, Vandevijvere S, Woodward A, Hornblow A, Richardson A, Burlingame $B$, et al. Proposed new industry code on unhealthy food marketing to children and young people: will it make a difference? N Z Med J. 2017;130(1450):94-101.

133. Théodore FL, Tolentino-Mayo L, Hernández-Zenil E, Bahena L, Velasco A, Popkin B, et al. Pitfalls of the self-regulation of advertisements directed at children on Mexican television. Pediatr Obes. 2017;12(4):312-9.

134. Uribe R, Fuentes-García A. The effects of TV unhealthy food brand placement on children. Its separate and joint effect with advertising. Appetite. 2015. https://doi.org/10.1016/j.appet.2015.03.030.

135. Vandevijvere S, Aitken C, Swinburn B. Volume, nature and potential impac of advertisements on Facebook and YouTube by food brands popular in New Zealand. N Z Med J. 2018;131(1473):14-24.

136. Vandevijvere S, Soupen A, Swinburn B. Unhealthy food advertising directed to children on New Zealand television: extent, nature, impact and policy implications. Public Health Nutr. 2017. https://doi.org/10.101 7/S1368980017000775.

137. Vandevijvere S, Sagar K, Kelly B, Swinburn B. Unhealthy food marketing to New Zealand children and adolescents through the internet. N Z Med J. 2017;130(1450):32-43.
138. Vandevijvere S, Swinburn B. Getting serious about protecting New Zealand children against unhealthy food marketing. N Z Med J. 2015; 128(1417):36-40.

139. Veerman JL, Van Beeck EF, Barendregt JJ, MacKenbach JP. By how much would limiting TV food advertising reduce childhood obesity. Eur J Pub Health. 2009. https://doi.org/10.1093/eurpub/ckp039.

140. Velazquez CE, Black JL, Kent MP. Food and beverage marketing in schools: a review of the evidence. Int J Environ Res Public Health. 2017. https://doi. org/10.3390/ijerph14091054.

141. Weber K, Story M, Harnack L. Internet food marketing strategies aimed at children and adolescents: a content analysis of food and beverage brand web sites. J Am Diet Assoc. 2006. https://doi.org/10.1016/j.jada.2006.06.014.

142. Wilson N, Signal L, Nicholls S, Thomson G. Marketing fat and sugar to children on New Zealand television. J Prev Med. 2006. https://doi.org/10.1 016/j.ypmed.2005.11.009.

143. World Health Organization. Marketing of food and non-alcoholic beverages to children: report of a WHO forum and technical meeting. Norway: World Health Organization; 2006

144. Zhou Z, Diao Q, Shao N, Liang Y, Lin L, Lei Y, Zheng L. The frequency of unhealthy food advertising on mainland chinese television (TV) and children and adolescents' risk of exposure to them. PLoS One. 2015. https:// doi.org/10.1371/journal.pone.0128746.

145. World Health Organization. A framework for implementing the set of recommendations on the marketing of foods and non-alcoholic beverages to children. Switzerland: World Health Organization; 2012.

146. Stead M, McDermott L, MacKintosh AM, Adamson A. Why healthy eating is bad for young people's health: identity, belonging and food. Soc Sci Med. 2011;72(7):1131-9.

147. Elliott C. Food as people: Teenagers' perspectives on food personalities and implications for healthy eating. Soc Sci Med. 2014;121:85-90.

148. World Health Organization. Monitoring and restricting digital Marketing of Unhealthy Products to children and adolescents. Copenhagen: World Health Organization Regional Office for Europe; 2019.

\section{Publisher's Note}

Springer Nature remains neutral with regard to jurisdictional claims in published maps and institutional affiliations.
Ready to submit your research? Choose BMC and benefit from:

- fast, convenient online submission

- thorough peer review by experienced researchers in your field

- rapid publication on acceptance

- support for research data, including large and complex data types

- gold Open Access which fosters wider collaboration and increased citations

- maximum visibility for your research: over $100 \mathrm{M}$ website views per year

At $\mathrm{BMC}$, research is always in progress.

Learn more biomedcentral.com/submissions 